\title{
International Business
}

Central European Review of Economics \& Finance

Vol. 25, No. 3(2018), pp. 51-65

DOI: $10.24136 /$ ceref.2018.015

Received: 8 March 2018. Accepted: 2 May 2018

Sławomir I. BUKOWSKI ${ }^{1}$, Robin GOWERS ${ }^{2}$

\section{AN ESTIMATE OF THE IMPACTS OF THE BANK OF ENGLAND'S QUANTITATIVE EASING PROGRAMME ON UK ECONOMIC GROWTH}

This paper reviews the reasons for and impacts of quantitative easing by the Bank of England. It analyses the macroeconomic impacts of this policy tool on the UK economy across the period 2008-2016. It compares the impacts of each round of quantitative easing to assess how the impacts changed over time. The authors implemented econometric analysis based on the VAR model. This analysis indicated that the Bank of England's monetary policy influenced GDP growth by a relatively small degree during the period studied. The impact of changes in the monetary base (M3) explained a bigger part of GDP growth than the decreases in interest rates and exchange rates. Over time the impact of this policy response diminished.

Keywords: monetary policy, interest rates, monetary aggregate, foreign exchange, GDP, model VAR.

JEL Classification Codes: E32, E52, F31.

\section{Introduction}

The aim of this paper is to investigate the impact of the Bank of England's quantitative easing policy on GDP growth in the UK economy over the period of 2008-2016.

\footnotetext{
${ }^{1}$ Professor of economics, dr habil., Department of International Business \& Finance, Faculty of Economics and Legal Sciences, K. Pułaski University of Technology and Humanities in Radom, Poland.

${ }^{2}$ Doctor of economics, senior lecturer, Writtle University College, Chelmsford, United Kingdom.
} 
The following hypotheses were formulated:

1. Quantitative easing, expressed in the money aggregate $M 3$ expansion, had a relatively poor impact on GDP growth, but changes in M3 explain bigger part of GDP growth over time compared to other factors.

2. The reduction in interest rates had a relatively stronger impact on GDP growth in the UK economy initially compared to the M3 expansion initially, but changes of interest rate explain smaller then M3 part of GDP growth in the longer run.

The authors implemented in the research econometric analysis based on the VAR model.

\section{Quantitative easing policy - some theoretical reflexions}

The roles of central banks and the need for their independence have been debated much over the centuries (see: Fischer 2015). The recent rise in the power of central banks was signalled by the defeat of inflation led by Paul Volcker at the Federal Reserve. On a Saturday night on October $6^{\text {th }} 1979$ Volcker signalled that the Fed was serious about defeating inflation by announcing they would target the money supply instead of interest rates. Consumer price inflation was indeed defeated but it was a brutal battle that resulted in the biggest downturn in the US since the Great Depression.

The great moderation period ${ }^{3}$ came to an end with the financial crisis that peaked on $29^{\text {th }}$ September 2008 ( 15 days after Lehman Brothers was allowed to collapse). Central banks came in and rescued the banking, financial and capitalist system. This rescue involved unprecedented levels of monetary policy implementation, initially with a move towards zero interest rates (ZIRP) and then injections of liquidity into the system (quantitative easing).

These policies gained further traction in 2012 when the European Central Bank had to join the party in order to prevent a second possible financial meltdown during the Eurozone crisis. On July $29^{\text {th }} 2012$ Mario Draghi stated, "Within our mandate, the ECB is ready to do whatever it takes to preserve the euro. And believe me, it will be enough." 4

Without these interventions there is no way of estimating how much worse off the global economy would have become. However, such interventions by unelected groups are affecting the level of trust that underpins the financial system.

The complexity of the modern world economy has left central bankers relying on models that do not reflect this nor always capture accurate data inputs. Keynes realised this issue in 1930 when he stated that:

"This is a nightmare, which will pass away with the morning. For the resources of nature and men's devices are just as fertile and productive as they were. The rate of

\footnotetext{
${ }^{3}$ Sometimes called the NICE period. Non-Inflationary Constant Expansion

${ }^{4}$ https://www.ecb.europa.eu/press/key/date/2012/html/sp120726.en.html (access 09.05.2018).
} 
our progress towards solving the material problems of life is not less rapid. We are as capable as before of affording for everyone a high standard of life-high, I mean, compared with, say, twenty years ago-and will soon learn to afford a standard higher still. We were not previously deceived. But to-day we have involved ourselves in a colossal muddle, having blundered in the control of a delicate machine, the working of which we do not understand. The result is that our possibilities of wealth may run to waste for a time-perhaps for a long time."

The fundamental task of central bank is influencing money supply for stabilisation of the economy, and then also consumer price inflation (see: Sławinski, 2014). „The central banks would emit money if the authorities of a country decided to monetize large-scale public debt; If the central bank started to directly lend to the government buying large amounts of treasury bonds immediately on the primary market" (Sławiński, 2014).

The central bank, in order to increase the money supply, has to persuade commercial banks to increase their bank loans. For this purpose, it increases the liquidity in the system. This can occur by swapping liquid reserves of commercial banks on accounts with the Central Bank on assets (securities) which are held by the commercial banks (Sławiński, 2014). If we assume that this type of central bank action will increase money supply, this should have two main affects. Firstly, on asset prices and secondly on GDP growth.

In terms of GDP, growth is affected by increase of money supply through the following channels:

Channel of interest rates: $M \uparrow \rightarrow i \downarrow \rightarrow K_{k} \downarrow \rightarrow I \uparrow \rightarrow D \uparrow \rightarrow P K B \uparrow$

Channel of foreign exchange: $M \uparrow \rightarrow E \uparrow \rightarrow N X \uparrow \rightarrow D \uparrow \rightarrow P K B \uparrow$

Channel of capital market: $M \uparrow \rightarrow i \downarrow \rightarrow D_{o} \downarrow \rightarrow D_{a} \uparrow \rightarrow P_{a} \uparrow \rightarrow I \uparrow \rightarrow D \uparrow \rightarrow P K B \uparrow$

Channel of credit: $M \uparrow \rightarrow V_{d} \uparrow \rightarrow K_{r}$

Where:

$M$ - money supply,

$I$ - interest rate,

$K_{k}-$ cost of capital,

1 - investment expenditure of the out of banking sector,

$E$ - foreign exchange - price of currency expressed in home currency unit,

$D$ - aggregated demand,

$K_{r}$ - supply of banking loans for enterprises and households,

$N X$ - net exports,

$V_{d}$ - value of bank deposits,

$D_{a}-$ demand for stocks,

$D_{0}$ - demand for bonds,

$P_{a}$ - rates of stocks. 
In terms of asset prices, the huge increase in central bank demand for government bonds has had a positive effect. So much so that many believe there are a number of asset prices bubbles in many areas. However, one could argue that investors are acting rationally (bubble or not) given the signals from central bankers that interest rates will be kept low for a long time and if markets fall QE will be extended. Yardeni et.al (2017) provide evidence of a positive correlation between the S\&P 500 Index and QE (see fig. 1).

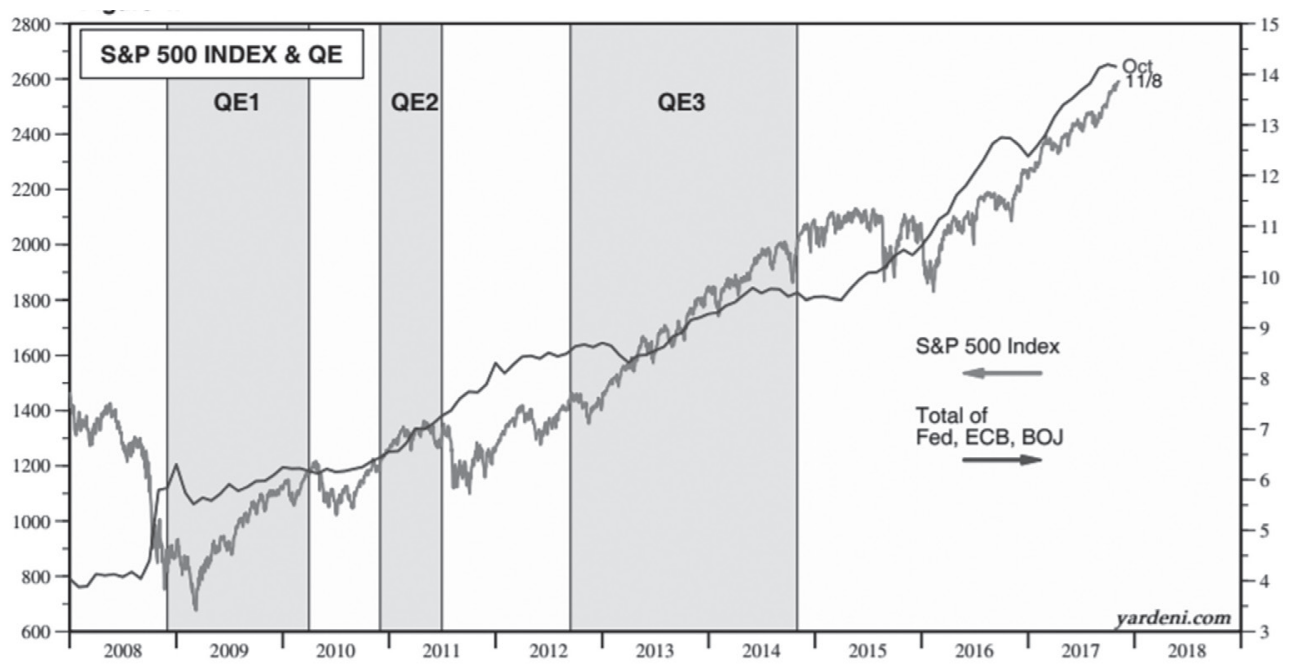

Note: QE1 $(11 / 25 / 08)=$ Fed starts buying $\$ 1.24 \mathrm{tn}$ in mortgage securities. QE1 expanded $(3 / 16 / 2009)=$ Fed starts buying $\$ 300 \mathrm{bn}$ in Treasuries . QE2 $(11 / 3 / 10)=$ Fed starts buying $\$ 600 \mathrm{bn}$ in Treasuries. QE3 $(9 / 13 / 12)=$ Fed starts buying \$40bn/month in mortgage securities (open ended). $\mathrm{QE} 3$ expanded $(12 / 12 / 12)=$ Fed starts buying $\$ 45 \mathrm{bn} / \mathrm{month}$ in Treasuries. Source: Federal Reserve Board, Standard \& Poor's and Haver Analytics.

Figure 1. S\&P 500 Index and QE

Source: Yardeni, et.al (2017).

When QE was first announced, and then expanded on, there was a belief that it would lead to inflation. However, it appears that the experience in the West is mirroring that of Japan - it appears that it has had little impact on consumer price inflation (many central banks are struggling to hit their inflation targets ${ }^{5}$ despite unprecedented levels of monetary injections).

However, injections of money into the economy can be reflected in two ways. Either by chasing up the prices of consumer goods (consumer price inflation) or via asset price inflation. If $Q E$ is indeed being shown in higher asset prices then its impacts on the 'real' (consumer facing) economy might be limited. If indeed this is the case then QE might actually destroy economic growth in the long run. The econometric model that follows helps test this hypothesis.

\footnotetext{
${ }^{5}$ Typically $2 \%$.
} 
A problem occurs with analysing the effects of quantitative easing during a period of a recession in which two crises overlapped in an economy - a financial and fiscal crisis. Like the majority of countries that employed QE, the UK combined this monetary stimulus with austerity measures. QE helped to stabilise countries but has also resulted in making it easier to service debts as real interest rates fell.

The resulting rise in asset prices and debt levels impacts the ability of models to distinguish the effects of each policy measure. Even more concerning, QE may lead to a decline in trust in the financial markets and central bankers (whom many see as boosting and protecting the wealth of the richest with little evidence of any trickle down effects).

With interest rates low banks margins are hit. Then the banks, instead of extending loans, they undertake proprietary trading (investing in assets on financial markets, mainly in the treasury bonds with a rating of "A" group). With central banks signalling that rates will remain low for the foreseeable future banks focus on the higher margins to be made from proprietary activities compared to the lower margins derived from their traditional lending. As a consequence low interest rates does not necessarily affect an increase in business investment and thus GDP growth. At the end, under the conditions of the widespread phenomenon of "rollover" debt, new capital from the sales of government bonds is largely „unproductive”, in the sense that it serves for the repayment the debt from the past rather than for any productive public investment. From the point of view of economic growth (via the transmission channels above), it would be ideal if the banks were creating loans for either new business ideas or to help successful business expand. Existing economic models have largely not adjusted to the fact that the dominant players in the financial markets are the central banks who have different incentives than just maximising their profits.

\section{Literature review}

There have been a number of studies into the quantitative impact of $\mathrm{QE}$ across a wide range of areas. Borio and Zabai (2016) provide a review of previous empirical studies in their paper. They come up with three main conclusions: "there is ample evidence that, to varying degrees, these measures have succeeded in influencing financial conditions even though their ultimate impact on output and inflation is harder to pin down; the balance of the benefits and costs is likely to deteriorate over time; and the measures are generally best regarded as exceptional, for use in very specific circumstances".

Borio and Zabai's findings relating to previous empirical studies of the impacts of QE on domestic bond yields and exchange rates (see appendix included in the end of paper) illustrate that there is a wide divergence in estimates of the impacts dependent on the underlying assumptions made within the models used. 
Going into the financial crisis in the UK many borrowers were over-leveraged. Initially consumers took advantage of the lower interest rates to deleverage. However as real incomes stagnate in the UK consumers are maintaining their lifestyles by using credit again. It would appear that consumers in the UK (and this trend is also reflected in many other countries where $\mathrm{QE}$ has been in place for a number of years) initially decided to postpone borrowing as central banks signaled that it would become even cheaper to borrow in the future. It has been this rise in borrowing that has kept the UK economy growing despite the uncertainties of Brexit.

I. Fuijowara's (2006) research concerned the Bank of Japan's monetary policy. The model used is an implemented MS VAR with five variables: industrial production, CPI, monetary base $(M)$, nominal effective currency rate of exchange and short-term loans interest rate on the interbank market. The period of research covers the years 19752002. The author indicated that the changes in monetary base and the interest rate influenced industrial production growth until 1996. However, when the Bank of Japan implemented zero-bound monetary policy after 1996 - there were no positive effects caused by interest rate reductions.

E. Griradin \& Z. Moussa (2010) investigation covered the period between 19852006 (monthly data) using an implemented model MS-SFAR. The results of their research indicate on the positive impact of the monetary base changes on the price level increases and the growth of the real economic activity.

D. Giannone, M. Lenza, H. Phill, L. Reichlin (2012) investigated the impact of the ECB non-standard measures of monetary policy on the euro are economy. The results of their Bayesian VAR model indicate the statistically significant impact of that policy on the production (increase of $2 \%$ ) and unemployment (decrease of the rate of unemployment by $0.6 \%$ ).

H. Chen, A. Cúrdia, A. Ferrero (2012) research, based on the macroeconomic model DSGE estimated that for the USA economy, that decreases in the interest rate caused GDP growth of $0.13 \%$, and quantitative easing policy caused GDP to grow by $0.6 \%$ and inflation by about $0.3 \%$.

G. Kapetanios, H. Mumtaz, I. Stevens, K. Theodoridis (2012) applied to the models VAR (BVAR, SVAR, TVP-VAR). The analysis of the models estimation results allowed them to determine the probable effects of quantitative easing in the UK implemented by the Bank of England in the period of 2009-2010. The results indicate that without quantitative easing the fall in GDP in 2009 would be much bigger and inflation would have been transformed into deflation.

J.-G. Suhuc (2016) research indicated that quantitative easing policy in the euro area in the period of $2015-2016$ induces growth of inflation by $0.6 \%$ and GDP growth by $0.6 \%$. 


\section{Statistical data and model}

In our research we used quarterly data from the period 2007:04-2016:04 concerning GDP, deflator of GDP, (GDP was estimated in constant prices from 1999), monetary aggregate M3, 3-moths interest rates LIBOR GBP, currency rate of exchange GBP/USD ${ }^{6}$.

In order to examine whether and how the changes in money supply, interest rates (monetary policy effect), and the currency rate of exchange in the UK affected economic growth in the period of the financial and fiscal crises and post-recession period (2008-2016), the following model was formulated:

$$
\begin{aligned}
& G D P_{t}=a_{10}+\sum_{i=1}^{4} a_{11 i} G D P_{t-i}+\sum_{i=1}^{4} a_{12 i} M 3_{t-i}+\sum_{i=1}^{4} a_{13 i} E_{t-i}+\sum_{i=1}^{4} a_{14 i} I 3_{t-i}+u_{19} \\
& M 3_{t}=a_{20}+\sum_{i=1}^{4} a_{21 i} G D P_{t-i}+\sum_{i=1}^{4} a_{22 i} M 3_{t-i}+\sum_{i=1}^{4} a_{23 i} E_{t-i}+\sum_{i=1}^{4} a_{24 i} I 3_{t-i}+u_{29} \\
& E_{t}=a_{30}+\sum_{i=1}^{4} a_{31 i} G D P_{t-i}+\sum_{i=1}^{4} a_{32 i} M 3_{t-i}+\sum_{i=1}^{4} a_{33 i} E_{t-i}+\sum_{i=1}^{4} a_{34 i} I 3_{t-i}+u_{39} \\
& I 3_{t}=a_{40}+\sum_{i=1}^{4} a_{41 i} G D P_{t-i}+\sum_{i=1}^{4} a_{42 i} M 3_{t-i}+\sum_{i=1}^{4} a_{43 i} E_{t-i}+\sum_{i=1}^{4} a_{44 i} I 3_{t-i}+u_{49}
\end{aligned}
$$

where:

$G D P_{t}-\log$ differences of Gross Domestic Product, $M 3_{t}-\log$ differences of monetary aggregate $M 3$,

$13_{t}$ - first differences of - month interest rate LIBOR GBP/USD,

$E_{t}-\log$ differences of currency rate of exchange GBP/USD,

$u$ - residuals.

The choice of the lag was based on the Akaike criterion (AIC) and Hannan-Quinn criterion (HQC).

\section{Results of the model's estimation}

The results Engle-Grnger's cointegration test indicate that the time series used in the VAR model are co-integrated (see below tab. 1).

Table 1. Results of Engle-Granger's cointegration test

Augmented Dickey-Fuller test for uhat including 4 lags of (1-L) uhat (max was 4, criterion AIC) sample size 32, unit-root null hypothesis: $\mathrm{a}=1$.

Model: $(1-\mathrm{L}) \mathrm{y}=(\mathrm{a}-1)^{*} \mathrm{y}(-1)+\ldots+\mathrm{e}$
Estimated value of $(\mathrm{a}-1):-1.36835$
Test statistic: tau_ct(4) $=-4.57306$
Asymptotic $p$-value 0.03382
1st-order autocorrelation coeff. for $\mathrm{e}:-0.102$
Lagged differences: $F(4,27)=2.213$ [0.0942]

Sorce: own estimation.

${ }^{6}$ The source of data was ECB Statistical Data Warehouse, data base of OECD, data base stooq.pl 
Also Johansen's cointegration test confirms cointegration of time series used in the VAR model (see below tab. 2).

Table 2. Results of Johansen's cointegration test: Number of equations $=4$, Lag order $=4$, Estimation period: 2007:4 - 2016:4 ( $T=37)$, Case 3: Unrestricted constant

Log-likelihood $=737.906$ (including constant term: 632.904)

Source: own estimation.

\begin{tabular}{|c|l|c|c|l|l|}
\hline Rank & Eigenvalue & Trace test & P-value & Lmax test & P-value \\
\hline 0 & 0.56069 & 56.882 & 0.0048 & 30.434 & 0.0177 \\
\hline 1 & 0.34529 & 26.448 & 0.1189 & 15.672 & 0.2547 \\
\hline 2 & 0.20346 & 10.776 & 0.2295 & 8.4169 & 0.3457 \\
\hline 3 & 0.061774 & 2.3593 & 0.1245 & 2.3593 & 0.1245 \\
\hline
\end{tabular}

Results of tests indicated that autocorrelation and effect ARCH does not exist (see table 3 ad 4).

Table 3. Results of autocorrelation test

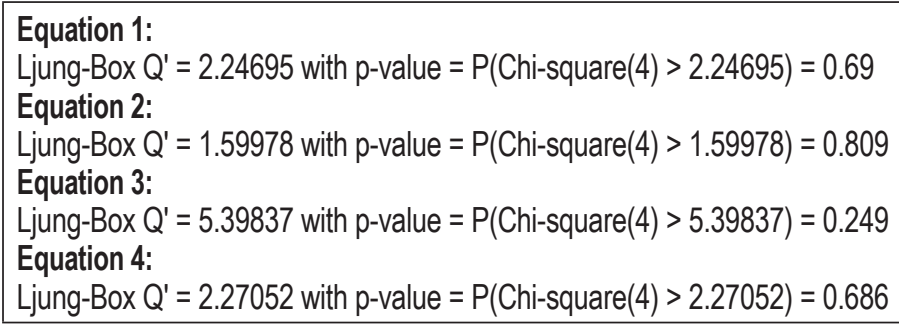

Source: own estimation.

Table 4. Results of test for ARCH of order 4

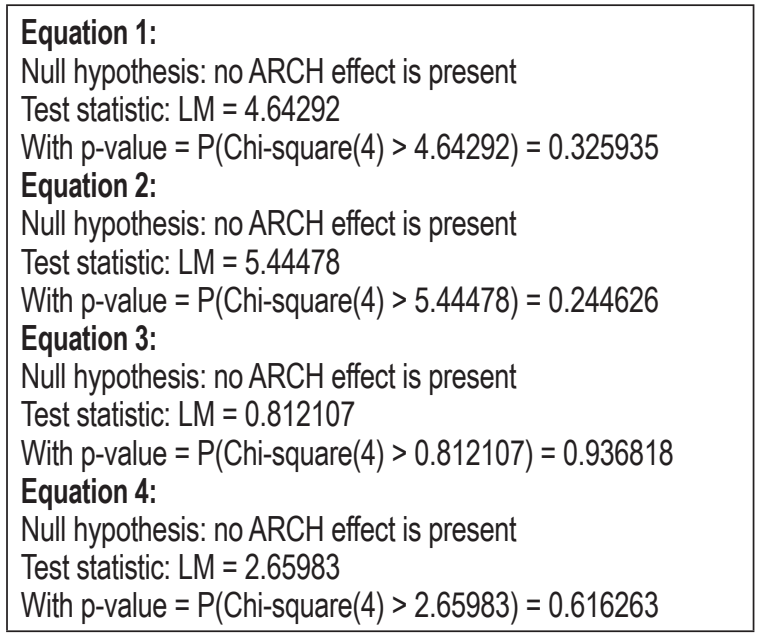

Source: own estimation. 
All VAR inverse roots are lower than 1. This result indicates that the constructed VAR model can be used in practice and impulse responses does not create non-stationary processes with an explosive course (see fig. 2).

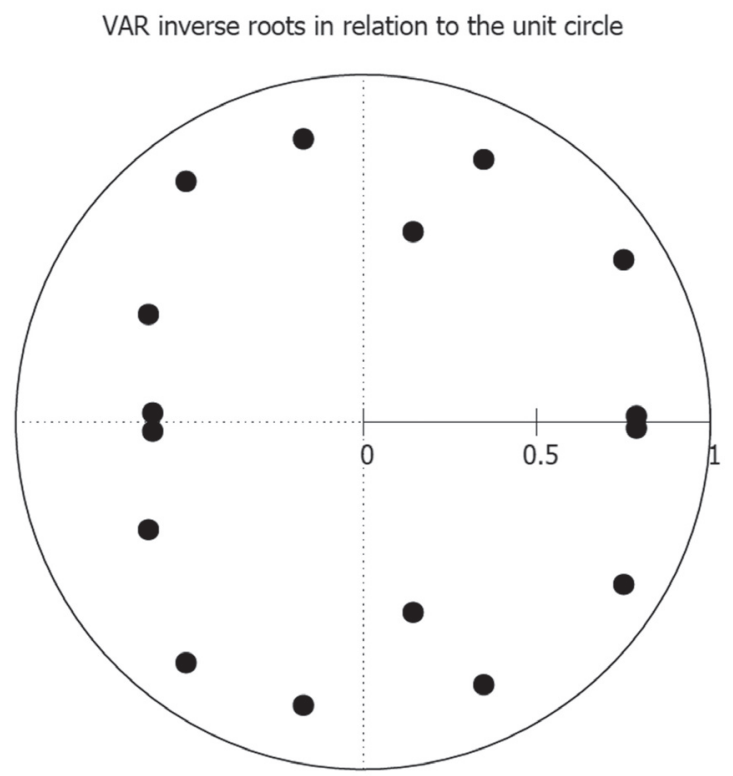

Figure 2. The roots of characteristic equation

Source: own estimation.

The analysis of the impulse responses (see fig. 3) indicates that the reaction of GDP growth in response to the impulse from the expansion in M3 was initially relatively weak. It appeared in the beginning of the $5^{\text {th }}$ quarter and began to go out after the $10^{\text {th }}$ quarter. The reaction of GDP growth in response to the impulse of the interest rate was much stronger initially and also appeared in the $5^{\text {th }}$ quarter. It began go out after the $10^{\text {th }}$ quarter. The reaction of GDP growth against the impulse of the currency rate of exchange was stronger than reactions against former impulses (M3 and interest rate) and appeared in the $5^{\text {th }}$ quarter, but it began to go out after the $10^{\text {th }}$ quarter. 

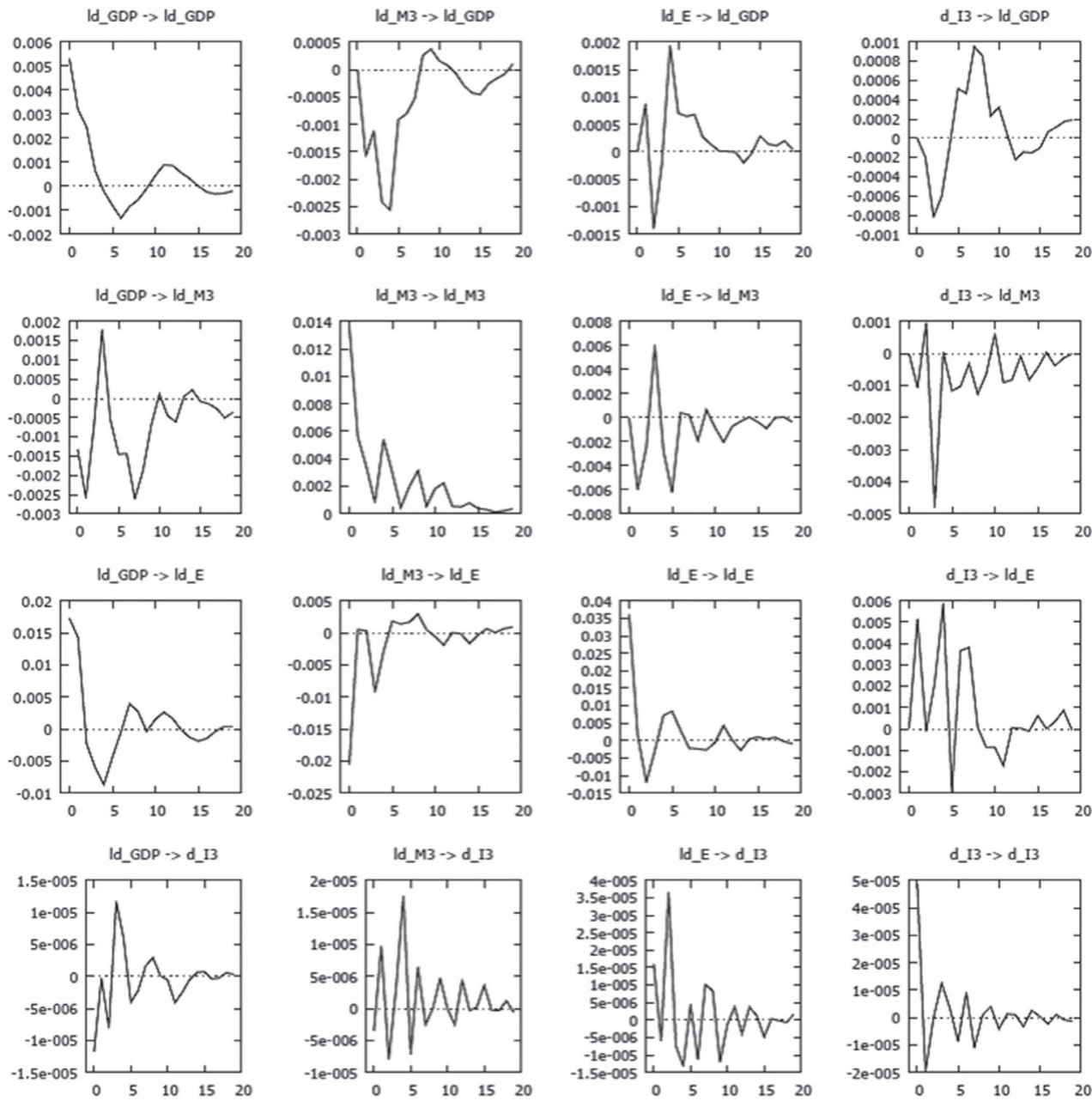

Figure 3. The impulse responses

Source: own estimation.

The analysis of forecast of variance decomposition indicates that changes of GDP growth was caused first of all by previous GDP growth (in 62,5\%), in 23,0 \% by changes of $\mathrm{M} 3$, in $4,4 \%$ by changes of interest rates, and in $10,1 \%$ by changes of currency rate of exchange (see fig. 4). 

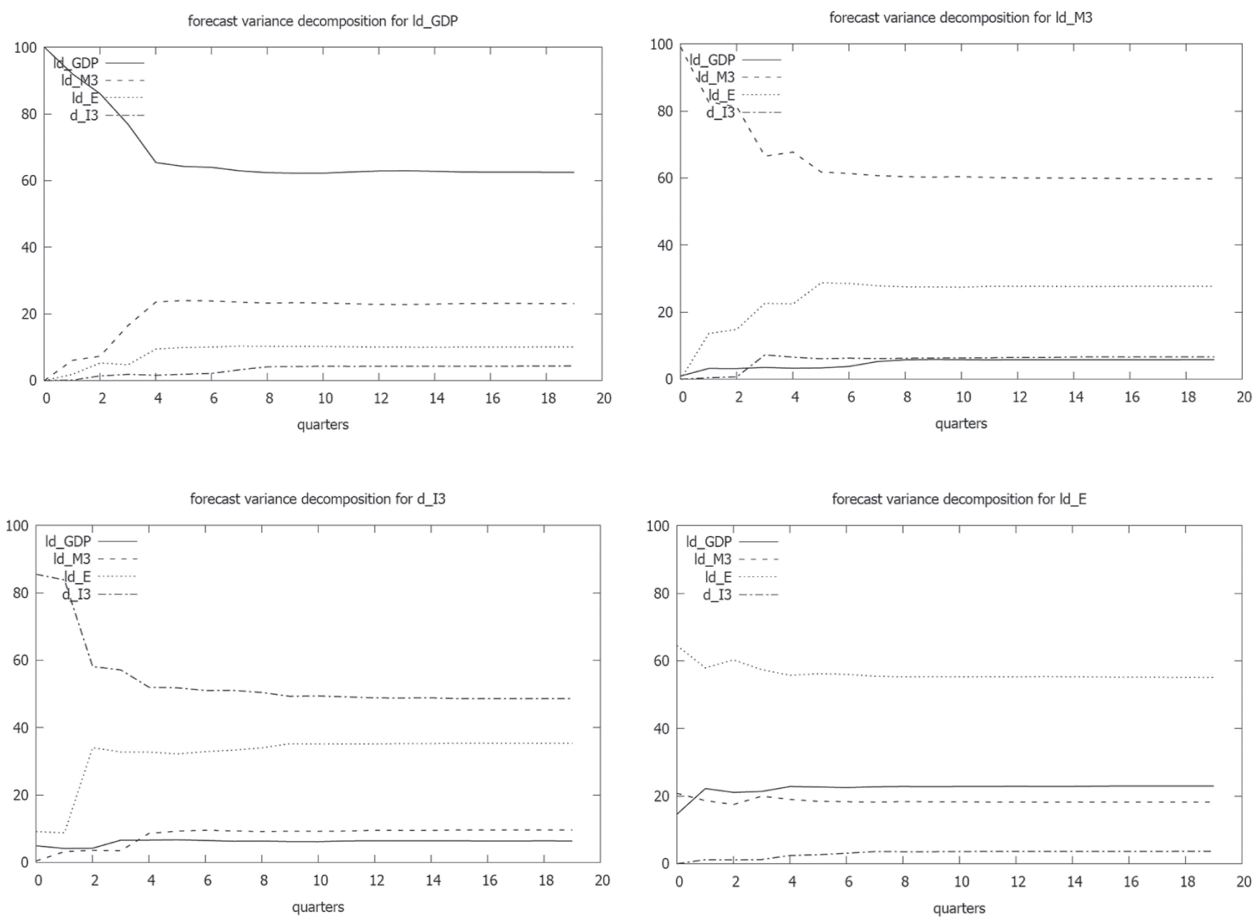

Figure 4. Forecast variance decomposition

Source: own estimation.

\section{Concluding remarks}

The analysis based on the model VAR allows us to formulate some important conclusions. First of all, the M3 expansion in the UK did not give so strong an effect in the stimulation of GDP growth despite expectations. If we look at the impulse response of GDP against M3, it explained $23.0 \%$ of the growth in GDP in the studied period. This was a larger impact compared to the effect of changes in the interest rate. The impact of interest rates on GDP was stronger than M3, if we look at the GDP impulse response against interest rate, but it explains a much smaller part of GDP growth. An important factor which influenced GDP growth was the exchange rate (GBP/USD). However, with both the US and the UK deploying QE programs at the same time it is hard to distinguish the individual policy effects. The explanation of the causes of that situation require further research in comparison with other countries as USA, Japan and also the euro area. 


\section{References}

Bank of England News Release (2017). Financial Policy Committee Statement from its policy meeting. 20 September 2017.

Borio, C., Zabai, A. (2016). Unconventional monetary policies: a re-appraisal. BIS Working Papers. No 570.

Chen, H., Cúrdia, A., Ferrero, A. (2012). The Macroeconomic Effects of Large-scale Asset Purchase Programmes. Economic Journal. 122(564). F289-F315.

Draghi, M. (2012). Speech by Mario Draghi. President of the European Central Bank at the Global Investment Conference in London 26 July 2012. Retrieved from https://www.ecb.europa.eu/ press/key/date/2012/html/sp120726.en.html (access 10.11.2017).

Economist (2017). As the global economy picks up, inflation is oddly quiescent. Retrieved from https://www.economist.com/news/finance-and-economics/21730930-central-banks-are-beginning-raise-interest-rates-anyway-global (access 12.11.2017).

Economist (2017). The Bubble Without Any Fizz. Published on 07.10.2017. Retrieved from https://www.economist.com/news/briefing/21729988-low-interest-rates-have-made-more-orless-all-investments-expensive-bubble-without-any-fizz?zid=295\&ah=0bca374e65f2354d553 956ea65f756e0 (access 11.11.2017).

Fischer, S (2015). Central Bank Independence. Speech at the 2015 Herbert Stein Memorial Lecture National Economists Club, Washington, D.C. Retrieved from https://www. federalreserve. gov/newsevents/speech/fischer20151104a.htm (access 06.11.2017).

Fuijiwara, I. (2006). Evaluating Monetary Policy and Nominal Interest Rates are Almost Zero. Journal of the Japanese and International Economy. Vol. 20. issue 3. September. 434-453.

Giannone, D., Lenza, M., Pill, H., Reichlin, L. (2012). The ECB and the Interbank Market. „Economic Journal". vol. 122(564). pp. F467-486.

Girardin, E., Moussa, Z. (2010). Quantitative easing Works: les sons from the unique experience in Japan 2001-2006. Retrieved from https://halshs.archies-ouvertes.fr/halshs-00459384 (access 10.05.2018).

Haldane, A. (2017). A Little More Conversation A Little Less Action. Bank of England Speeches. Retrieved from http://www.bankofengland.co.uk/publications/Documents/speeches/2017/ speech971.pdf (access 29.10.2017).

Haldane, A., Roberts-Sklar, M., Wieladek, T., Young, C. (2016). Staff Working Paper No. 624. $\mathrm{QE}:$ the story so far. Bank of England.

Kapetanios, G., Mumtaz, H., Stevens, I., Theodoridis, K. (2012). Assessing the Economy-Wide Effects of Quantitative Easing. „Bank of England Working paper”. No 443.

Keynes, J. M., (1930). London: The Nation \& Athenæum, issues of December 20 and December 27 (First Edition).

ONS (2017). Statistical Bulletin: Household disposable income and inequality in the UK: financial year ending 2016. 
Sławiński, A. (2014). Zmniejszenie się skuteczności polityki pieniężnej w wyniku recesji wywołanej kryzysem bankowym: Przypadek Japonii i strefy euro. Referat na Konferencję Katedr Finansów organizowaną przez Wydział Finansów Uniwersytetu Ekonomicznego w Krakowie, Krynica 22-24 września 2014.

Suhuc, J-G. (2016). The ECB's Asset Purchase Programme: A Model - Based evaluation. „Economic Letters" 145C. pp. 136-140.

Yardeni, E., Quintana, M. (2017). Global Economic Briefing: Central Bank Balance Sheets. Yardeni Research. 


\section{Appendix}

\begin{tabular}{|c|c|c|c|c|}
\hline \multicolumn{4}{|c|}{ Impact of balance sheet policies on domestic yields and the exchange rate } & Table 4 \\
\hline \multirow[t]{2}{*}{ Study } & \multirow[t]{2}{*}{ Method } & \multicolumn{3}{|c|}{ Estimates } \\
\hline & & $\begin{array}{c}\Delta 10 \text {-year } \\
\text { Treasury yield }(\mathrm{bp})\end{array}$ & $\begin{array}{c}\Delta 30 \text {-year MBS } \\
\text { yield (bp) }\end{array}$ & $\Delta \mathrm{FX}(\%)$ \\
\hline \multicolumn{5}{|l|}{ United States } \\
\hline \multicolumn{5}{|c|}{ QE1 - $\$ 1.75$ trillion MBS; $\$ 300$ billion Treasuries; $\$ 172$ billion agency securities } \\
\hline $\begin{array}{l}\text { Krishnamurthy and } \\
\text { Vissing-Jorgensen (2011) }\end{array}$ & Event study & $-107^{12}$ & $-107^{1 b}$ & \\
\hline Gagnon et al (2011) & Event study & $-91^{2 a}$ & $-113^{2 b}$ & \\
\hline $\begin{array}{l}\text { Hancock and Passmore } \\
\text { (2011) }\end{array}$ & Time series regressions & & & $-44^{3 c}$ \\
\hline $\begin{array}{l}\text { Christensen and } \\
\text { Rudebusch (2012) }\end{array}$ & $\begin{array}{l}\text { Event study, affine no-arbitrage } \\
\text { model of the term structure }\end{array}$ & $\begin{array}{c}-89^{43} \\
(-60,-33,-7)\end{array}$ & & \\
\hline D'Amico and King (2013) & Cross-section regression & $-30^{5 \mathrm{~s}}$ & & \\
\hline D’Amico et al (2012) & Time series regression & $\begin{array}{l}-35^{63} \\
(66,34)\end{array}$ & & \\
\hline $\begin{array}{l}\text { Bauer and Rudebusch } \\
\text { (2014) }\end{array}$ & $\begin{array}{l}\text { Affine no-arbitrage model of the } \\
\text { term structure }\end{array}$ & $\begin{array}{l}-89^{72} \\
(38,62)\end{array}$ & & \\
\hline Neely (2015) & Event study & $-94^{8 a}$ & & $-5.98^{\text {sc }}$ \\
\hline Chadha et al (2016) & Time-series regression & -90 to $-115^{\%}$ & & \\
\hline \multicolumn{5}{|c|}{ QE2 - $\$ 600$ billion Treasuries } \\
\hline \multicolumn{5}{|c|}{ MEP - \$667 billion long-term Treasuries purchased; \$667 billion short-term Treasuries sold } \\
\hline $\begin{array}{l}\text { Krishnamurthy and } \\
\text { Vissing-Jorgensen (2011) }\end{array}$ & Event study & $-30^{100}$ & $-8^{10 b}$ & \\
\hline Swanson (2011) & Event study & $-16^{112}$ & & \\
\hline Hamilton et al (2012) & Time series regression & $-22^{12 \mathrm{a}}$ & & \\
\hline D’Amico et al (2012) & Time series regression & $\begin{array}{l}-45^{13 a} \\
(78,22)\end{array}$ & & \\
\hline \multicolumn{5}{|c|}{ All programmes (includes QE3, $\$ 823$ billion MBS; $\$ 790$ billion Treasuries) } \\
\hline Swanson (2015) & Time series regression & $-7.46^{14 a}$ & & $-0.26^{1 \mathrm{c}}$ \\
\hline \multicolumn{5}{|l|}{ United Kingdom } \\
\hline \multicolumn{5}{|l|}{ QE - $\$ 375$ billion gilts } \\
\hline & & $\Delta$ gilts yield (bp) & & $\Delta \mathrm{FX}(\%)$ \\
\hline Joyce et al (2011) & Event study & $\begin{array}{c}-100 \mathrm{bp} p^{15 a} \\
(10,90)\end{array}$ & & $-4^{15 c}$ \\
\hline Joyce and Tong (2012) & $\begin{array}{l}\text { Event study, time series } \\
\text { regressions }\end{array}$ & $\begin{array}{c}-97.6^{16 \mathrm{a}} \\
(2.5)\end{array}$ & & \\
\hline $\begin{array}{l}\text { Christensen and } \\
\text { Rudebusch (2012) }\end{array}$ & $\begin{array}{l}\text { Event study, affine no-arbitrage } \\
\text { model of the term structure }\end{array}$ & $\begin{array}{c}-43^{17 a} \\
(47,-135,-12)\end{array}$ & & \\
\hline McLaren et al (2014) & Event study & $\begin{array}{c}-93^{18 a} \\
(52)\end{array}$ & & \\
\hline
\end{tabular}

Source: Borio, C., Zabai, A. (2016). 


\section{Euro area}

APP - planned purchases of C1.14 trillion until September 2016

\begin{tabular}{|c|c|c|c|}
\hline & & $\begin{array}{c}\Delta 10 \text {-year } \\
\text { Treasury yield (bp) }\end{array}$ & $\Delta F X(\%)$ \\
\hline Altavilla et al (2015) & Event study & $-47^{190}$ & $-12^{15 x}$ \\
\hline \multicolumn{4}{|c|}{$\begin{array}{l}\text { Japan } \\
\text { Monetary easing since } 2008\end{array}$} \\
\hline & & $\begin{array}{c}\Delta 10 \text {-year } \\
\text { Treasury yield (bp) }\end{array}$ & $\Delta F X(\%)$ \\
\hline Lam (2011) & Event study & $-24^{200}$ & $-0.3^{20 c}$ \\
\hline Ueda (2012) & Announcement effects & $-9.9^{21 \mathrm{a}}$ & $-0.52^{21 \mathrm{~b}}$ \\
\hline $\begin{array}{l}\text { Hausman and Wieland } \\
\text { (2014) }\end{array}$ & Announcement effects & $-11.4^{22 a}$ & $3.55^{220}$ \\
\hline Imakubo et al (2015) & Models of the term structure & $-80^{230}$ & \\
\hline
\end{tabular}

${ }^{12 a b}$ Cumulative change (Table 1). ${ }^{2 a b}$ Cumulative effect based on baseline event set (Table 1). ${ }^{3 \mathrm{c}}$ This is not a yield change but the change in abnormal MBS pricing (ie the difference between actual and predicted), in basis points, during the announcement period (Table 3, entry $(1,9)) .{ }^{42}$ Actual yield change (first line) and split of actual yield change between signalling channel and portfolio balance channel (plus residual), in per cent, based on preferred term structure models (Table 4 and Table 8, last row). $\$$ The first line reports the stock effect, based on comparison of actual and counterfactual yield curves (Figure 5), while the second line is the flow effect on eligible securities on purchase day (see Section 4.3.2). ${ }^{62}$ Yield change and split between local supply effects $(66 \%)$ and duration effects (34\%); see discussion at the end of Section 6.72 Actual yield change (first line) and split of model-implied yield change (-94 bp) between signalling channel and portfolio balance channel, in per cent, based on restricted risk pricing specification of the term structure model (Table 5). ${ }^{3 a}$ Cumulative effect of buy and sell events (Table 2). ${ }^{8 c}$ Average change in the exchange rate (measured as the foreign currency price of 1 dollar), cumulative effect of buy and sell events (Table 3). ${ }^{2}$ Impact on 5-year forward 10-year rate (Figure 3). ${ }^{20 a b}$ Cumulative change based on two-day window (Table 5). ${ }^{100} \mathrm{Not}$ significant. ${ }^{112}$ Cumulative change based on first four announcements (Table 3). ${ }^{122}$ A $\$ 400$ maturity swap at the zero lower bound is estimated to reduce yields by 13 bp (Table 5); the actual swap was $\$ 667$ billion and since the model is linear, one obtains $667 / 400^{*} 13 \mathrm{bp}=22 \mathrm{bp}$. ${ }^{13 \mathrm{~J}}$ Yield change and split between local supply effects (78\%) and duration effects (22\%); see discussion at the end of Section 6. ${ }^{14}$ Impact of a change in purchases about $\$ 300$ billion larger than anticipated by markets (Section 3 and Tables 2 and 3). $1 \mathrm{k}$ Average change in the exchange rate (measured as the foreign currency price of 1 dollar) after a change in purchases about $\$ 300$ billion larger than anticipated by markets (Section 3 and Table 4, authors' calculations). ${ }^{152}$ Cumulative change in gilt yields and split across signalling channel (10\%) and portfolio balance channel (90\%) (Chart 9). ${ }^{16}$ Cumulative change in sterling exchange rate, measured as the foreign currency price of one pound (Chart 17). ${ }^{162}$ First row reports the average change in yield following QE announcement in medium- to long-term gilts (Table 3, average of last row excluding the first entry), while the second row reports the further yield reduction in eligible gilt yields that happened ahead of each auction (flow effects, see Section 6). ${ }^{172}$ Actual yield change (first line) and split of actual yield change between signalling channel and portfolio balance channel (plus residual), in per cent, based on preferred term structure models (Tables 12 and 15, last row). ${ }^{18}$ Total decline in five- to 25 -maturity gilt yields, and share of local supply effect (Section 2.2 and Table 4). ${ }^{19}$ Cumulative change based on controlled event study with two-day window (Table 1). ${ }^{19}$ Percentage change based on controlled event study with two-day window, exchange rate measured as the dollar price of 1 euro (Table 6). 20 c Cumulative effect (Table 3a). $20 \%$ Expressed as number of dollars per yen, not significant (Table 3a). 2ta Comprehensive Monetary Easing programme announcement ( 5 October 2010) effect (Table 5, penultimate row). This is not an event study, so a significance level is not provided. ${ }^{21 b}$ Comprehensive Monetary Easing programme announcement effect on the exchange rate, expressed as the yen price of 1 dollar (so a negative entry is a yen appreciation) ${ }^{22} \mathrm{QQE}$ announcement (4 April 2013) effect (Table 2). This is not an event study, so a significance level is not provided. ${ }_{22 \mathrm{~b}} \mathrm{QQE}$ announcement effect on the exchange rate, measured as the yen price of 1 dollar (Table 2). This is not an event study, so a significance level is not provided. ${ }^{23}$ Maximum impact of QQE programme computed as gap between actual and natural yield curve (Figure 8, bottom right panel).

Source: Borio, C., Zabai, A. (2016). 